\title{
Predicting Severe Infection and Effects of Hypogammaglobulinemia During Therapy With Rituximab in Rheumatic and Musculoskeletal Diseases
}

DOI:

10.1002/art.40937

\section{Document Version \\ Accepted author manuscript}

Link to publication record in Manchester Research Explorer

Citation for published version (APA):

Md Yusof, M. Y., Vital, E. M., McElvenny, D. M., Hensor, E. M. A., Das, S., Dass, S., Rawstron, A. C., Buch, M. H., Emery, P., \& Savic, S. (2019). Predicting Severe Infection and Effects of Hypogammaglobulinemia During Therapy With Rituximab in Rheumatic and Musculoskeletal Diseases. Arthritis \& rheumatology (Hoboken, N.J.), 71(11), 1812-1823. https://doi.org/10.1002/art.40937

\section{Published in:}

Arthritis \& rheumatology (Hoboken, N.J.)

\section{Citing this paper}

Please note that where the full-text provided on Manchester Research Explorer is the Author Accepted Manuscript or Proof version this may differ from the final Published version. If citing, it is advised that you check and use the publisher's definitive version.

\section{General rights}

Copyright and moral rights for the publications made accessible in the Research Explorer are retained by the authors and/or other copyright owners and it is a condition of accessing publications that users recognise and abide by the legal requirements associated with these rights.

\section{Takedown policy}

If you believe that this document breaches copyright please refer to the University of Manchester's Takedown Procedures [http://man.ac.uk/04Y6Bo] or contact uml.scholarlycommunications@manchester.ac.uk providing relevant details, so we can investigate your claim.

\section{OPEN ACCESS}




\section{Journal}

Arthritis and Rheumatology

\section{Article Type}

Full-Length Article

\section{Title}

Predicting severe infection and effects of hypogammaglobulinaemia during therapy with rituximab in rheumatic and musculoskeletal diseases

\section{Authors}

Md Yuzaiful Md Yusof ${ }^{1,2} \mathrm{PhD}$ MRCP

Edward M Vital ${ }^{1,2} \mathrm{PhD}$ MRCP

Damien M McElvenny ${ }^{3}$ PhD CStat CSci

Elizabeth M A Hensor ${ }^{1,2} \mathrm{PhD}$

Sudipto Das ${ }^{1,2}$ MRCP

Shouvik Dass ${ }^{1,2}$ MA FRCP

Andy C Rawstron ${ }^{4} \mathrm{PhD}$

Maya $\mathrm{H}$ Buch ${ }^{1,2} \mathrm{PhD}$ FRCP

Paul Emery ${ }^{1,2}$ MA MD, FMedSci*

Sinisa Savic ${ }^{1,2}$ PhD FRCPath*

*Dr Savic and Prof Emery contributed equally as the last authors to this manuscript

\section{Affiliations}

1. Leeds Institute of Rheumatic and Musculoskeletal Medicine, University of Leeds, Chapel Allerton Hospital, Chapeltown Road, Leeds, LS7 4SA

2. NIHR Leeds Biomedical Research Centre, Leeds Teaching Hospitals NHS Trust, Leeds, UK

3. Institute of Population Health, University of Manchester, Oxford Road, Manchester M13 9PL, UK

4. Haematological Malignancy Diagnostic Service, Leeds Teaching Hospitals NHS Trust, Leeds, UK

\section{Correspondence}

Sinisa Savic

Level 4, Clinical Science Building,

St James' University Hospital,

Leeds LS9 7TF

United Kingdom

Email: s.savic@leeds.ac.uk

Tel: +44 113-34-38413

Fax: +44 1133924991

\section{Keywords}

B-cells, Immunoglobulin, Infection, Rheumatoid arthritis, Rituximab, Systemic lupus erythematosus

\section{Word Count}

3998 


\section{Competing Interests:}

Dr Md Yusof, Prof McElvenny, Dr Hensor, Dr Das and Prof Rawstron have no conflict of interest.

Dr Vital has received honoraria and research grant support from Roche, GSK and AstraZeneca. Dr Dass has received honoraria from Roche and GSK.

Prof Buch has received consultant fees from Abbvie, Bristol Myers Squibb, Eli Lilly, MSD, Pfizer Ltd, Roche-Chugai, Sandoz and research grants paid to her employer from Pfizer Ltd, Roche and UCB.

Professor Emery has received consultant fees from BMS, Abbott, Pfizer, MSD, Novartis, Roche and UCB. He has received research grants paid to his employer from Abbott, BMS, Pfizer, MSD and Roche.

Dr Savic has received honoraria from Novartis, SOBI and Sire and grant support from Novartis, Swedish Orphan Biovitrum, Octapharma and CSL Behring

\section{Funding Info:}

This research in whole or in part was funded/supported by Octapharma and the National Institute for Health Research (NIHR) and NIHR Leeds Biomedical Research Centre based at Leeds Teaching Hospitals NHS Trust; (DRF-2014-07-155). The views expressed are those of the author(s) and not necessarily those of the NHS, the NIHR or the Department of Health. 


\section{ABSTRACT}

Objectives: To evaluate predictors of serious infections events (SIEs) during rituximab (RTX) therapy and effects of hypogammaglobulinaemia concerning SIE rates, humoral response and its persistence post-RTX discontinuation in the treatment of rheumatic and musculoskeletal diseases (RMDs).

Methods: A retrospective longitudinal study was conducted in a single centre in 700 RTXtreated RMD patients. Immunoglobulins were measured at baseline and 4-6 months after each cycle. Baseline predictors of SIEs were assessed using multivariable logistic regression; for cycles 2-4 mixed-effects logistic regression were used.

Results: 507(72\%) had rheumatoid arthritis, 94(13\%) systemic lupus erythematosus, 49(7\%) ANCA-associated vasculitis and 50(8\%) other RMDs. 281 SIEs were recorded in 176 patients (9.8/100 PY). Predictors of SIEs comprised non-RTX-specific comorbidities (previous history of SIE, cancer, chronic lung disease, diabetes, heart failure), higher corticosteroid dose and RTX-specific factors; low $\operatorname{IgG}(<6 \mathrm{~g} / \mathrm{L})$ both at baseline and subsequently, RTX-associated neutropaenia, higher IgM and longer time-to-RTX retreatment, but not B-cell numbers or depletion status. Of 103 patients with low IgG, SIEs rates were higher in those with low baseline IgG (16.4/100 PY) or acquired it during/post-RTX (21.3/100 PY) versus normal IgG (9.7/100 PY), 5/8(64\%) had impaired humoral response to pneumococcal and haemophilus following vaccination challenge and only 4/11(36\%) had IgG normalised after switching bDMARDs.

Conclusion: Immunoglobulin should be monitored at baseline and before each RTX cycle to identify patients at risk of SIEs. Individualised benefit-risk assessment should be undertaken in those with lower IgG as this is a consistent SIE predictor and may increase infection profiles when RTX is switched to different therapies.

(250 words) 


\section{Introduction}

Rituximab (RTX) has been licensed for the treatment of moderate to severe rheumatoid arthritis (RA) for over a decade as well as approved for remission induction of anti-neutrophil cytoplasmic antibody (ANCA)-associated vasculitis $(A A V)(1,2)$. Despite the failure of randomised controlled trials (RCTs) in meeting their primary endpoints in systemic lupus erythematosus (SLE)(3, 4), primary Sjogren's syndrome (pSS)(5, 6) and inflammatory myopathies(7), RTX is commonly used off-label in these indications and other various rheumatic and musculoskeletal diseases (RMDs), often in cases that are refractory to other systemic therapies(8-11). However, the immunomodulatory properties of biological disease modifying anti-rheumatic drugs (bDMARDs) in general including RTX have raised safety concerns, prompting careful evaluation in randomised clinical trials (RCTs) and intensive postmarketing surveillance(12). Data from RCTs and long-term extension (LTE) studies of RTX in various RMDs had shown no major safety signals(3, 4, 13-15). Nevertheless, RCTs and their LTE studies sub-selected patients who tolerated the therapy, while those with comorbidities were often excluded from trials(16). Therefore, real-world data from cohort studies are needed.

B-cell depletion targeted at the CD20 molecule is temporary due to the sparing of stem cells(17). Following an initial response, the majority of RTX-treated RMD patients ultimately relapse, requiring repeat cycles to recapture response. Repeat cycles with RTX are effective( 8 , 18-22). However, attrition of immunoglobulin levels may occur(23, 24). Data from a registry and small number of observational studies reported that low gammaglobulin (IgG) pre-RTX increased the odds of serious infection events (SIEs) in the initial 12 months follow-up postRTX(25-27). Nevertheless, predictors of SIEs during repeat cycles have not been reported. Moreover, evidence for immunoglobulin monitoring is also scarce. Thus, the effects of treatment-induced hypogammaglobulinaemia on the rates of SIEs and persistence of low 
immunoglobulin levels following RTX discontinuation need to be evaluated. This is fundamental as the latter issue could affect infection outcomes when patients are switched to different bDMARDs.

Another potential concern is alteration of the B-cell repertoire during depletion with RTX. The reconstitution of B-cell compartment following each cycle of depletion may not fully recapitulate the previous repertoire (although long-lived plasma cells are mostly spared from depletion)(28). It is possible that long-term perturbation of the immune system in this fashion may lead to impaired host defence. Moreover, long-term, the failure to mount an adequate response to pathogens may put chronically B-cell depleted patients at risk of infection. Longterm data on the association between maintenance of low B-cell numbers and SIEs have not been reported.

Therefore, the objectives of this study were to evaluate predictors of SIEs within the first 12 months and with repeat cycles of RTX in the treatment of RMDs and assess effects of secondary hypogammaglobulinaemia in terms of SIE rates, humoral response to vaccination challenge and its persistence following treatment discontinuation, with a view to establishing a treatment algorithm for safe RTX administration.

\section{Methods}

\section{Patients and Design}

A retrospective longitudinal cohort study was conducted in the first 700 consecutive patients with RMDs, treated with at least one course of RTX in Leeds, UK between January 2002 and May 2017. Inclusion criteria were (i) adults ( $\geq 18$ years old); (ii) fulfilling the classification criteria for autoimmune RMD including RA(29), SLE(30), AAV(31), pSS(32), inflammatory myopathies(33), systemic sclerosis(34) and others $(35,36)$ and (iii) at least 3 months follow-up post-RTX. 


\section{Ethical approval information}

This study did not require a formal ethical approval because all treatment decisions were made prior to evaluation of data, in accordance with the UK National Health Service Research Ethics Committee guidelines. B-cell subset analysis was performed in an accredited clinical diagnostic laboratory (Haematological Malignancy Diagnostic Service (HMDS), Leeds Teaching Hospitals NHS Trust). This is a routine clinical test in patients receiving treatment with RTX in our region. The off-label uses of RTX in non-licensed indications were approved by Leeds Teaching Hospitals National Health Service (NHS) Trust Drug and Therapeutic Committee.

\section{Treatment}

All patients received a first cycle of therapy consisting of $100 \mathrm{mg}$ of methylprednisolone and $1000 \mathrm{mg}$ of RTX (MabThera) given intravenously on days 1 and 14. Further cycles consisting of the same regimen were repeated on clinical relapse. For RA, 96/506 (19\%) of the patients received repeat treatment with half-dose regimen (500mg x 2) following a European League Against Rheumatism (EULAR) response(37) in the previous cycle, in line with our departmental practice. This decision was left to investigators' clinical judgement.

Intravenous cyclophosphamide was commonly used as first line remission induction agent for severe and refractory AAV and SLE. This was administered using similar regimen as per CYCLOPS trial(38). Following a further relapse or non-response to cyclophosphamide, treatment was switched to RTX. To analyse the effect of prior treatment with cyclophosphamide followed by RTX on immunoglobulins, 20 patients with AAV and SLE (with immunoglobulin data available) were studied. Cyclophosphamide was also used for remission induction of RA-related interstitial lung disease (RA-ILD) and rheumatoid vasculitis. 
Continuation of a stable or a reduced dose of concomitant conventional synthetic DMARDs (csDMARDs) and oral prednisolone were left to investigators' discretion with the aim to stop the latter if clinical response for the respective disease was achieved at 6 months.

\section{Clinical data and outcomes}

Age, sex, disease duration, diagnosis, comorbidities including a previous history of any type of cancer, chronic lung disease such as ILD, bronchiectasis and asthma (with recurrent exacerbations), moderate to severe heart failure, diabetes, a previous history of SIE within 12 months prior to RTX, number of previous csDMARDs, bDMARDs, previous treatment with cyclophosphamide, concomitant prednisolone, prednisolone dose, concomitant csDMARDs (excluding anti-malarials only), RTX dose, time-to-RTX retreatment and RTX-associated neutropaenia (RAN) were recorded. RAN was defined as i) an absolute neutrophil count $<2.0 \times 10^{9} / \mathrm{L}$ occurring at least 4 weeks post-RTX and ii) neutropaenia prior to RTX, druginduced neutropaenia or alternative plausible explanation (e.g. Felty's syndrome) were excluded.

SIEs were defined as those resulted in hospitalisation for $>24$ hours or required intravenous antibiotics. Data for SIEs were gathered thoroughly and extensively from hospital admission records using the electronic Patient Access Service system, electronic health records, pathology results server, clinic, correspondence letters and medical case notes.

\section{Laboratory assessments}

Full blood count was processed at a single accredited diagnostic laboratory. Total serum immunoglobulin levels were measured by nephelometry at pre- and post- cyclophosphamide, RTX baseline and 4-6 months after each cycle (normal range for IgM: 0.5-2.0 g/L; IgA: 0.84.0 g/L and IgG: 6.0-16.0 g/L). Secondary hypoglobulinaemia was defined as a level of IgM, IgA or IgG which was below its respective lower limit of normal (LLN) for at least 4 months post-RTX. 
Specific antibody responses to tetanus, haemophilus and pneumococcal tests were performed in patients with low IgG and/or SIE in the previous RTX cycle using enzyme-linked immunosorbent assays. Ranges for inadequate, sub-optimal and adequate antibody levels were $<0.01,0.01-0.15$ and $>0.15 \mathrm{IU} / \mathrm{mL}$ for tetanus; $<0.15,0.15-1.0$ and $>1.0 \mu \mathrm{g} / \mathrm{mL}$ for haemophilus and <10, 10-30 and $>30 \mu \mathrm{g} / \mathrm{mL}$ for pneumococcal. Patients with suboptimal/inadequate response to either antibody were treated with the appropriate vaccine and these tests were repeated at 4-6 weeks post-vaccination.

Peripheral blood B-cell subsets (naïve, memory and plasmablast) were measured using highly sensitive flow cytometry as previously described(39) at baseline, week 2 and week 6 without knowledge of patients' clinical status other than time since RTX. Complete B-cell depletion was defined as counts $<0.0001 \times 10^{9}$ cells $/ \mathrm{L}$.

\section{Statistical analyses}

Patients contributed person-years (PYs) of follow-up between the date of first RTX cycle and either the date of death, transferred to different hospitals, switched to different bDMARDs or last follow-up visit. To calculate the rates of SIEs, the total number of SIEs were divided by the total follow-up in PYs as defined above. No other censoring rules were applied to those with repeated infections or in statistical modelling.

Associations between categorical variables were tested by Fisher's exact test while for continuous variables, either Student's t-test or Mann-Whitney U test was used, depending on data type and distribution.

Some data for immunoglobulins and B-cells were missing due to samples not being processed on the day. Multiple imputation by chained equations was used to estimate these missing data and other data values at both baseline and follow-up. 10 multiple imputation sets were used to provide stability of results(40). 
To assess baseline predictors of SIEs in the following 12 months post-RTX, all (imputed) putative variables were first evaluated using univariable analyses. Multivariable analyses using logistic regression with multiple imputation were undertaken using forward selection and backwards elimination with a p-value of $<0.25$ associated with the deviance used for inclusion in and exclusion from the model.

Data for Cycles 2-4 (C2-4) were analysed as more than two-thirds of the patients received at least 4 RTX cycles and 4 cycles were considered long enough for baseline risk factors to be predictive. For analyses in $\mathrm{C} 2-\mathrm{C} 4$, linear mixed-effects logistic regression; a statistical model comprised both fixed and random intercepts(41) was used based on complete-case analysis. The same criteria as for the logistic modelling were used for inclusion and exclusion of variables from this final model. For analyses of predictors of SIEs, two-sided $p<0.10$ was considered significant while two-sided $\mathrm{p}<0.05$ was used for other analyses.

Statistical analyses were performed using Stata v.13 (StataCorp. 2013. Stata Statistical Software: Release 13. College Station, TX: StataCorp LP. and GraphPad Prism v8.0 (GraphPad, La Jolla, CA, USA) for Windows.

\section{Results}

\section{Patient characteristics}

Of 700 patients with RMDs who were treated with RTX, 550 patients were female, median age (IQR) at RTX initiation was 58 (46-68) years and median disease duration (IQR) 7.9 (3.415.0) years. Most patients had RA, $n=507(72 \%) .57 / 700(8.1 \%)$ had a previous history of cancer $[$ breast $=16$, bladder $=6$, lymphoma $=5$, squamous cell carcinoma of the skin/tongue/nose $=5$, basal cell carcinoma of the skin=4, colon=4, chronic lymphocytic leukaemia $=3$, lungs $=3$, ovary $=3$, renal $=2$, cervix $=1$, gastric $=1$, melanoma $=1$, parotid $=1$, prostate $=1$ and thyroid=1]. Of these, 24/57 were treated with chemotherapy, 6/57 had low IgG 
$(<6 \mathrm{~g} / \mathrm{L})$ at RTX initiation and median cancer diagnosis to first cycle RTX (IQR) 4.3 (1.4-9.5) years.

Total follow-up: 2880 PYs. Median (IQR) RTX cycles was 3 (2-5). Baseline characteristics are described in Table 1.

\section{Rate, sources and timing of SIEs from first cycle RTX}

Overall, there were 281 SIEs recorded in 176 patients (9.8/100 PY). The rates of SIEs were slightly lower in autoimmune connective tissue disease (AI-CTD) (9.2/100 PY) compared to RA (10.0/100 PY). The rates of SIEs were generally declining over time (except for a blip increase at 7-8 years), reflecting modest numbers as well as less patients with SIEs at the later follow-up (online supplementary Figure S1).

Most SIEs were due to lower respiratory tract infection; $n=170(61 \%)$. Sources of SIEs are illustrated in online supplementary Figure S2.

In the following 12 months from RTX initiation, 89 SIEs were recorded in 75 patients. Of these, the proportions of patients who had their first SIE within 6 weeks, 12 weeks, 26 weeks, 38 weeks and 52 weeks from Cycle 1 RTX were 12/75 (16\%), 26/75 (35\%), 54/75 (72\%), $62 / 75(83 \%)$ and 75/75 (100\%) respectively. Cumulative survival of SIE over the first 80 weeks from first cycle RTX is illustrated in online supplementary Figure S3.

\section{Opportunistic infections}

There were 8 opportunistic infections recorded. These were disseminated varicella zoster=2, mycobacterium $=2$ [one patient presented with reactivation of mycobacterium tuberculosis as septic arthritis of the right ankle while another had mycobacterium avium complex in the lungs], cytomegalovirus $=2$, disseminated candidiasis $=1$ and pneumocystis jiroveci pneumonia $=1$. The last was observed in a patient who was subsequently diagnosed as having HIV infection. 


\section{Chronic hepatitis infections}

$15 / 700(2.1 \%)$ and $7 / 700(1 \%)$ of the patients had previous hepatitis $\mathrm{B}$ and $\mathrm{C}$ infections respectively i.e. Anti-HBc and Anti-HCV positive. None of them had detectable Hepatitis B or C viral load prior to RTX. During RTX therapy, 14/15 of the patients with previous hepatitis B infections were treated with prophylaxis lamivudine (1 patient was non-compliant to either lamivudine or entecavir) while no prophylaxis was administered to those with previous hepatitis C infections. Post-RTX, no case of reactivation of both hepatitis was observed.

\section{Baseline predictors of SIEs within 12 months of RTX initiation}

In Cycle 1, data for immunoglobulins and B-cells were available for 666/700 (95\%) and $597 / 700(85 \%)$ of the patients respectively.

In multivariable analysis, a previous history of cancer, SIE, chronic lung disease, RAN and low IgG were associated with increased odds of SIEs in the following 12 months from RTX initiation. A diagnosis of RA was associated with lower risk of SIEs (Table 2).

\section{Predictors of low IgG prior to RTX initiation}

Since low IgG pre-RTX was independently predictive of SIE, its risk factors were evaluated. In multivariable analysis, older age, a previous history of cancer, SIE and therapy with cyclophosphamide were associated with increased odds of low $\operatorname{IgG}$ at baseline. While a diagnosis of RA was associated with normal IgG (online supplementary Table S1).

Effect of remission induction with cyclophosphamide followed by RTX on immunoglobulin levels

Remission induction with cyclophosphamide led to a profound decline in almost all immunoglobulin classes for AAV and SLE (except IgM and IgA for SLE) at 6 months posttherapy. $\operatorname{IgM}, \operatorname{IgA}$ and $\operatorname{IgG}$ levels for both diseases (except IgM in SLE) remained substantially lower than pre-cyclophosphamide levels at 18 months. 
Following a subsequent relapse or non-response to cyclophosphamide, remission induction and maintenance was switched to RTX (the latter using retreatment-on-relapse strategy). Using this strategy, IgA and IgG levels remained stable up to 3 cycles in AAV. While in SLE, progressive reduction in all immunoglobulin classes over the 3 RTX cycles were observed, albeit their levels were still above the LLN (Figure 1).

\section{Predictors of SIEs during repeat RTX cycles}

For C2-C4, all plausible variables were analysed using mixed-effects logistic regression analysis. As no study has reported on the relevant change in immunoglobulin level parameters for a longitudinal study, we tested several variables including percentage change of immunoglobulin level of each cycle in relation to immunoglobulin level at RTX baseline, absolute and relative difference in immunoglobulin between pre- and post-RTX for each cycle. However, none of these were predictive in multivariable analysis. Hence, we selected the first variable, with the strongest association with SIEs to be included in the model building.

There were 595 patients with an infection outcome for C2 but only $411(69.1 \%)$ with complete covariable information were studied. In multivariable analysis, baseline comorbidities including a previous history of cancer, SIE, chronic lung disease, heart failure and diabetes, higher corticosteroid dose, as well as pre-RTX variables of each cycle including RAN, longer time-to-RTX retreatment and higher IgM level were associated with increased odds of SIEs. Higher IgG level was associated with lower odds of SIEs. Lower B-cell subset numbers and depletion status were not independently associated with SIEs (Table 3).

\section{Infection rates in patients with hypoglobulinaemia}

To assess infection outcomes in patients with RMDs who had hypoglobulinaemia, we divided them into 3 groups: i) low Ig levels at RTX C1 baseline; ii) low Ig levels during/post-RTX and iii) never developed low Ig. Only IgM and IgG were evaluated since frequency of IgA $<$ LLN was the lowest; $32 / 670(4.8 \%)$. 
For IgM, the rates of SIEs were similar in those with low IgM at RTX C1 baseline (10.6/100 PY), before acquiring low Ig during RTX (9.8/100 PY) and those with normal IgM (9.2/100 PY). While the highest rate of SIEs was observed in those who acquired low IgM during/postRTX (14/100 PY).

In contrast, the rates of SIEs were markedly higher in those with low IgG at RTX C1 baseline (16.4/100 PY) or acquired it during/post-RTX (21.3/100 PY) versus those with normal IgG (9.7/100 PY) or before acquiring low IgG during RTX (12.1/100 PY) (Table 4).

\section{Effect on specific antibody responses in patients with low IgG}

Specific antibody responses to tetanus, pneumococcal and haemophilus assays were tested in 29 patients (as decided by physicians) with low IgG and/or SIEs in the previous RTX cycle. Of these, the proportions of patients with sub-optimal/inadequate response to tetanus, haemophilus and pneumococcal were 2/29 (7\%), 21/29 (72\%) and 17/29 (59\%) respectively. $8 / 29$ of these patients had repeat tests at 6 weeks following vaccination challenge. Of these, $5 / 8$ continued to have impaired responses (sub-optimal/inadequate) to both haemophilus and pneumococcal (Figure 2(A-B)). Three patients with inadequate responses above were treated with immunoglobulin replacement (IGR) therapy.

\section{Effect on immunoglobulins following switch to different bDMARDs}

$103 / 700(14.7 \%)$ of the patients had low $\operatorname{IgG}$ either at baseline or at least 4 months duration during RTX therapy. Of these, 31/103 (30.1\%) discontinued RTX [deaths=15 (10=infection of which 2 had baseline low IgG; $2=$ metastatic cancer; $2=$ multi-organ failure and 1=heart failure); switched to different bDMARDs=11; left hospital=3 and no longer required RTX=2].

Post-switch immunoglobulin data were available for all 11 patients. Of these, only $4 / 11(36 \%)$ had their IgG normalised after at least 2 years post-switch. Of those who remained with low IgG post-switch, 2/7 had to stop subsequent bDMARDs and one required IGR therapy (Figure 2C and online supplementary Table S2). 


\section{Efficacy of immunoglobulin replacement therapy}

Overall, only 7/700 (1\%) of the patients in this cohort were treated with IGR due to recurrent infections despite prophylactic antibiotics and/or hypogammaglobulinaemia. as recommended by expert consensus(42). These were $\mathrm{RA}=3, \mathrm{SLE}=2, \mathrm{AAV}=1$ and anti-phospholipid syndrome=1. Median time (range) from first cycle RTX to IGR was 3.7 (0-7.2) years. PostIGR, 6/7 had IgG normalised, 3/7 had normal IgA and 2/7 had normal IgM (Figure 2D). Number and severity of infections reduced in all patients. Median duration (range) of therapy was $3.7(0.5-10)$ years. Cessation of IGR was only achieved in 1/7 of the patients.

\section{Discussion}

This report presents the most complete infection safety data on the use of RTX in treating various RMDs from a real-world perspective. By carefully reviewing records of every patient to capture all infection episodes in the largest single centre cohort study to date, our findings provide insights on predictors of SIEs as well as a foundation for safety monitoring of RTX. In this study, a high rate of SIEs (9.8/100 PY) was observed, compared to data from RCTs and LTE studies of RTX in RA (3.94/100 PY)(13) and registries of RTX in RMDs (ranging from 5.0-6.6 PY) $(25,43,44)$. The high SIE rate in this cohort could be contributed to channelling bias as the patients comprised those with multiple comorbidities including chronic lung disease (a relative contraindication for other bDMARDs), a previous history of cancer and SIE. Patients with these risk factors were enriched in this RTX-treated population, thus led to an increase in adverse events reported. Moreover, efficacy RCTs (and meta-analyses derived from them) are of limited value in capturing adverse events in those with multiple comorbidities(16) while for registry study, complete data depended on the quality of reporting from the participating investigators(45).

The finding from a French registry(25) that low $\mathrm{IgG}$ at baseline was associated with increased risk of SIE within 12 months of RTX initiation was validated in this study. However, other 
important risk factors including RAN, a previous history of cancer and SIE were not reproduced from their dataset. Importantly, the advantages of this study compared to the registry including longer duration of follow-up, methods of dealing with missing data were better defined and the majority of data for immunoglobulins were available (95\% versus $49 \%$ in the registry). In this study, all SIEs only occurred in patients with a neutrophil count $<0.5 \times 10^{9} / \mathrm{L}$. Nevertheless, the incidence of RAN in these RMD patients was low, 25/700 (3.6\%), which was nearly similar to those reported by a registry study of RTX in RMDs(46). As a risk factor for SIE, a previous history of cancer appeared to be independent of IgG since the rates of low IgG at RTX baseline between those with and without prior history of cancer were about the same; $6 / 57(10.5 \%)$ and 28/643 (4.3\%). No other association between type of cancer, cancer treatment or timing from cancer diagnosis to first cycle RTX and SIE could be deduced due to frequency of patients with a previous history of cancer in this cohort.

This study is also the first to identify predictors of SIEs with repeat RTX cycles including baseline comorbidities and higher corticosteroid dose, as well as RTX-specific factors such as pre-RTX IgG, IgM levels, RAN and longer time-to-RTX retreatment. The last may be an artefact due to reluctance to re-treat those with low IgG. Higher IgM level could represent an initial phase of infection(47) or high disease activity(48), which could increase infection risk. Moreover, in line with the consensus statement on the use of RTX in RA(2), our findings not only provided rationale for immunoglobulin monitoring for below or above LLN but also added that the degree of recovery or increment of IgG level (as measured before retreatment of each cycle) would reduce the risk of post-treatment infection.

Other studies reported risk factors for hypogammaglobulinaemia including lower IgG level pre-RTX(27) while conflicting evidence for prior treatment with cyclophosphamide $(24,49)$. This study identified older age, a previous history of cancer, SIE and therapy with cyclophosphamide as predictors of low $\operatorname{IgG}$ at baseline. These factors as well as other 
predictors of SIEs as described above need to be taken into account when counselling patients on safety before commencing therapy with RTX. Furthermore, for those with low baseline immunoglobulin levels and are deemed to be in higher risk groups (with multiple comorbidities), our data suggest that reduction of corticosteroid may be beneficial. Although the use of half-dose RTX regimen was not predictive of SIEs, it is worth nothing that this study was not designed and powered to answer this question.

It is also important to note that this acquired hypogammaglobulinaemia could not be solely attributed to RTX. This study showed that remission induction for severe AAV and SLE with cyclophosphamide led to a marked decline in almost all immunoglobulin classes up to 18 months. This concurred with a study by Venhoff et al., who also showed that a single cycle of RTX following cyclophosphamide further worsened the decline in IgM and IgG to below LLN levels(50). In contrast, using a retreatment-on-clinical relapse strategy, IgA and $\operatorname{IgG}$ levels remained stable over time in AAV in this study. Meanwhile, reduction in all immunoglobulin classes post-RTX in SLE (albeit their levels were still above the LLN) could be attributed to RTX efficacy. Overall then, retreatment-on-relapse strategy as implemented in this cohort led to the lowest rate $(1 \%)$ of patients who subsequently required IGR therapy compared to fixed retreatment strategy i.e. every 6 to 12 -monthly (ranging from 4-11\%)(24, 49). Importantly, our findings raised an important question; should RTX be used as a first line agent for remission induction for severe AAV and SLE from safety perspective?

The continued efficacy of B-cell depletion in RA, SLE and other RMDs depends on repeated RTX cycles to maintain depletion or low levels of B-cells. This is the first study to show that in a fully adjusted model, both low B-cell numbers and the depth of depletion post-RTX were not associated with increased risk of SIEs.

This study has some limitations. First, the lack of control group as well as enough samples/power to detect infection safety differences regarding RTX dosage regimen and 
retreatment strategy limits its safety interpretation. Another potential limitation was heterogeneity of the patients, although this could also improve the generalisability of our findings. Next, for repeat cycles, we lost $31 \%$ of the data in the final model due to incomplete covariates information. However, we had evaluated the consistency of predictors in the final model (using complete-case analysis) against analyses of predictors of SIEs in each C2-C4 (using multiple imputation). Baseline comorbidities, corticosteroid dose, RAN and IgG were consistent predictors of SIEs while time-to-RTX retreatment and IgM were only predictive in Cycle 4 (data not shown). Lastly, concomitant therapy with csDMARDs and daily oral corticosteroid were used in $73 \%$ and $43 \%$ of the patients respectively, thus infection could not be attributed to RTX alone.

In conclusion, immunoglobulin should be monitored at baseline and before each RTX cycle, particularly in patients with comorbidities and low baseline immunoglobulin levels in order to discern those at risk of SIEs. Individualised benefit-risk assessment regarding RTX retreatment decision is needed in those with lower IgG as this is a consistent predictor of SIE and may increase infection profiles when RTX is switched to different bDMARDs. 


\section{References}

1. Medicines.org.uk. Mabthera 100mg Concentrate for Solution for Infusion. Summary of Product Characteristics (SPC) - (eMC). [online] Available at: https://www.medicines.org.uk/emc/product/3801/smpc [Accessed 28 Oct. 2018].

2. Buch MH, Smolen JS, Betteridge N, Breedveld FC, Burmester G, Dorner T, et al. Updated consensus statement on the use of rituximab in patients with rheumatoid arthritis. Ann Rheum Dis. 2011;70(6):909-20.

3. Merrill JT, Neuwelt CM, Wallace DJ, Shanahan JC, Latinis KM, Oates JC, et al. Efficacy and safety of rituximab in moderately-to-severely active systemic lupus erythematosus: the randomized, double-blind, phase II/III systemic lupus erythematosus evaluation of rituximab trial. Arthritis Rheum. 2010;62(1):222-33.

4. Rovin BH, Furie R, Latinis K, Looney RJ, Fervenza FC, Sanchez-Guerrero J, et al. Efficacy and safety of rituximab in patients with active proliferative lupus nephritis: the Lupus Nephritis Assessment with Rituximab study. Arthritis Rheum. 2012;64(4):1215-26.

5. Devauchelle-Pensec V, Mariette X, Jousse-Joulin S, Berthelot JM, Perdriger A, Puechal X, et al. Treatment of primary Sjogren syndrome with rituximab: a randomized trial. Ann Intern Med. 2014;160(4):233-42.

6. Bowman SJ, Everett CC, O'Dwyer JL, Emery P, Pitzalis C, Ng WF, et al. Randomized Controlled Trial of Rituximab and Cost-Effectiveness Analysis in Treating Fatigue and Oral Dryness in Primary Sjogren's Syndrome. Arthritis Rheumatol. 2017;69(7):1440-50.

7. Oddis CV, Reed AM, Aggarwal R, Rider LG, Ascherman DP, Levesque MC, et al. Rituximab in the treatment of refractory adult and juvenile dermatomyositis and adult polymyositis: a randomized, placebo-phase trial. Arthritis Rheum. 2013;65(2):314-24.

8. Aguiar R, Araujo C, Martins-Coelho G, Isenberg D. Use of rituximab in systemic lupus erythematosus: a single center experience over 14 years. Arthritis Care Res (Hoboken). 2016.

9. Vital EM, Dass S, Buch MH, Henshaw K, Pease CT, Martin MF, et al. B cell biomarkers of rituximab responses in systemic lupus erythematosus. Arthritis Rheum. 2011;63(10):3038-47.

10. Dass S, Bowman SJ, Vital EM, Ikeda K, Pease CT, Hamburger J, et al. Reduction of fatigue in Sjogren syndrome with rituximab: results of a randomised, double-blind, placebocontrolled pilot study. Ann Rheum Dis. 2008;67(11):1541-4.

11. Ebbo M, Grados A, Samson M, Groh M, Loundou A, Rigolet A, et al. Long-term efficacy and safety of rituximab in IgG4-related disease: Data from a French nationwide study of thirty-three patients. PLoS One. 2017;12(9):e0183844.

12. Md Yusof MY, Vital EM, Buch MH. B Cell Therapies, Approved and Emerging: a Review of Infectious Risk and Prevention During Use. Curr Rheumatol Rep. 2015;17(10):65. 
13. van Vollenhoven RF, Fleischmann RM, Furst DE, Lacey S, Lehane PB. Longterm Safety of Rituximab: Final Report of the Rheumatoid Arthritis Global Clinical Trial Program over 11 Years. J Rheumatol. 2015;42(10):1761-6.

14. Specks U, Merkel PA, Seo P, Spiera R, Langford CA, Hoffman GS, et al. Efficacy of Remission-Induction Regimens for ANCA-Associated Vasculitis. New England Journal of Medicine. 2013;369(5):417-27.

15. Jones RB, Cohen Tervaert JW, Hauser T, Luqmani R, Morgan MD, Peh CA, et al. Rituximab versus Cyclophosphamide in ANCA-Associated Renal Vasculitis. New England Journal of Medicine. 2010;363(3):211-20.

16. Buch MH, Silva-Fernandez L, Carmona L, Aletaha D, Christensen R, Combe B, et al. Development of EULAR recommendations for the reporting of clinical trial extension studies in rheumatology. Annals of the Rheumatic Diseases. 2015;74(6):963-9.

17. Rehnberg M, Amu S, Tarkowski A, Bokarewa MI, Brisslert M. Short- and long-term effects of anti-CD20 treatment on B cell ontogeny in bone marrow of patients with rheumatoid arthritis. Arthritis Research \& Therapy. 2009;11(4):R123.

18. Emery P, Deodhar A, Rigby WF, Isaacs JD, Combe B, Racewicz AJ, et al. Efficacy and safety of different doses and retreatment of rituximab: a randomised, placebo-controlled trial in patients who are biological naive with active rheumatoid arthritis and an inadequate response to methotrexate (Study Evaluating Rituximab's Efficacy in MTX iNadequate rEsponders (SERENE)). Ann Rheum Dis. 2010;69(9):1629-35.

19. Rubbert-Roth A, Tak PP, Zerbini C, Tremblay JL, Carreno L, Armstrong G, et al. Efficacy and safety of various repeat treatment dosing regimens of rituximab in patients with active rheumatoid arthritis: results of a Phase III randomized study (MIRROR). Rheumatology (Oxford). 2010;49(9):1683-93.

20. Md Yusof MY, Shaw D, El-Sherbiny YM, Dunn E, Rawstron AC, Emery P, et al. Predicting and managing primary and secondary non-response to rituximab using B-cell biomarkers in systemic lupus erythematosus. Ann Rheum Dis. 2017;76(11):1829-36.

21. Md Yusof MY, Vital EM, Das S, Dass S, Arumugakani G, Savic S, et al. Repeat cycles of rituximab on clinical relapse in ANCA-associated vasculitis: identifying B cell biomarkers for relapse to guide retreatment decisions. Ann Rheum Dis. 2015;74(9):1734-8.

22. Cartin-Ceba R, Golbin JM, Keogh KA, Peikert T, Sanchez-Menendez M, Ytterberg SR, et al. Rituximab for remission induction and maintenance in refractory granulomatosis with polyangiitis (Wegener's): ten-year experience at a single center. Arthritis Rheum. 2012;64(11):3770-8.

23. Smith RM, Jones RB, Guerry M-J, Laurino S, Catapano F, Chaudhry A, et al. Rituximab for remission maintenance in relapsing antineutrophil cytoplasmic antibodyassociated vasculitis. Arthritis \& Rheumatism. 2012;64(11):3760-9.

24. Besada E, Koldingsnes W, Nossent JC. Serum immunoglobulin levels and risk factors for hypogammaglobulinaemia during long-term maintenance therapy with rituximab in patients with granulomatosis with polyangiitis. Rheumatology. 2014;53(10):1818-24. 
25. Gottenberg JE, Ravaud P, Bardin T, Cacoub P, Cantagrel A, Combe B, et al. Risk factors for severe infections in patients with rheumatoid arthritis treated with rituximab in the autoimmunity and rituximab registry. Arthritis Rheum. 2010;62(9):2625-32.

26. Barmettler S, Ong M, Farmer JR, Choi H, Walter J. Association of immunoglobulin levels, infectious risk, and mortality with rituximab and hypogammaglobulinemia. JAMA Network Open. 2018;1(7):e184169.

27. Boleto G, Avouac J, Wipff J, Forien M, Dougados M, Roux C, et al. Predictors of hypogammaglobulinemia during rituximab maintenance therapy in rheumatoid arthritis: A 12year longitudinal multi-center study. Seminars in arthritis and rheumatism. 2018;48(2):149-54.

28. Chen DR, Cohen PL. Living life without B cells: is repeated B-cell depletion a safe and effective long-term treatment plan for rheumatoid arthritis? International journal of clinical rheumatology. 2012;7(2):159-66.

29. Aletaha D, Neogi T, Silman AJ, Funovits J, Felson DT, Bingham CO, 3rd, et al. 2010 rheumatoid arthritis classification criteria: an American College of Rheumatology/European League Against Rheumatism collaborative initiative. Ann Rheum Dis. 2010;69(9):1580-8.

30. Petri M, Orbai AM, Alarcon GS, Gordon C, Merrill JT, Fortin PR, et al. Derivation and validation of the Systemic Lupus International Collaborating Clinics classification criteria for systemic lupus erythematosus. Arthritis Rheum. 2012;64(8):2677-86.

31. Jennette JC, Falk RJ, Bacon PA, Basu N, Cid MC, Ferrario F, et al. 2012 revised International Chapel Hill Consensus Conference Nomenclature of Vasculitides. Arthritis Rheum. 2013;65(1):1-11.

32. Shiboski CH, Shiboski SC, Seror R, Criswell LA, Labetoulle M, Lietman TM, et al. 2016 American College of Rheumatology/European League Against Rheumatism classification criteria for primary Sjogren's syndrome: A consensus and data-driven methodology involving three international patient cohorts. Ann Rheum Dis. 2017;76(1):9-16.

33. Lundberg IE, Tjärnlund A, Bottai M, Werth VP, Pilkington C, Visser Md, et al. 2017 European League Against Rheumatism/American College of Rheumatology classification criteria for adult and juvenile idiopathic inflammatory myopathies and their major subgroups. Annals of the Rheumatic Diseases. 2017;76(12):1955-64.

34. van den Hoogen F, Khanna D, Fransen J, Johnson SR, Baron M, Tyndall A, et al. 2013 classification criteria for systemic sclerosis: an American college of rheumatology/European league against rheumatism collaborative initiative. Ann Rheum Dis. 2013;72(11):1747-55.

35. Alarcón-Segovia D. Mixed connective tissue disease and overlap syndromes. Clinics in Dermatology. 1994;12(2):309-16.

36. Deshpande V, Khosroshahi A. Diagnostic guidelines for IgG4-related disease with a focus on histopathological criteria. Diagnostic Histopathology. 2013;19(4):119-27.

37. van Gestel AM, Prevoo ML, van 't Hof MA, van Rijswijk MH, van de Putte LB, van Riel PL. Development and validation of the European League Against Rheumatism response criteria for rheumatoid arthritis. Comparison with the preliminary American College of 
Rheumatology and the World Health Organization/International League Against Rheumatism Criteria. Arthritis Rheum. 1996;39(1):34-40.

38. de Groot K, Harper L, Jayne DR, Flores Suarez LF, Gregorini G, Gross WL, et al. Pulse versus daily oral cyclophosphamide for induction of remission in antineutrophil cytoplasmic antibody-associated vasculitis: a randomized trial. Ann Intern Med. 2009;150(10):670-80.

39. Dass S, Rawstron AC, Vital EM, Henshaw K, McGonagle D, Emery P. Highly sensitive B cell analysis predicts response to rituximab therapy in rheumatoid arthritis. Arthritis Rheum. 2008;58(10):2993-9.

40. White IR, Royston P, Wood AM. Multiple imputation using chained equations: Issues and guidance for practice. Statistics in medicine. 2011;30(4):377-99.

41. Breslow NE, Clayton DG. Approximate Inference in Generalized Linear Mixed Models. Journal of the American Statistical Association. 1993;88(421):9-25.

42. Wijetilleka S, Jayne DR, Mukhtyar C, Ala A, Bright PD, Chinoy $\mathrm{H}$, et al. Recommendations for the management of secondary hypogammaglobulinaemia due to $\mathrm{B}$ cell targeted therapies in autoimmune rheumatic diseases. Rheumatology (Oxford). 2018.

43. Tony HP, Burmester G, Schulze-Koops H, Grunke M, Henes J, Kotter I, et al. Safety and clinical outcomes of rituximab therapy in patients with different autoimmune diseases: experience from a national registry (GRAID). Arthritis Res Ther. 2011;13(3):R75.

44. Silva-Fernández L, De Cock D, Lunt M, Low AS, Watson KD, the B-RACG, et al. Serious infection risk after 1 year between patients with rheumatoid arthritis treated with rituximab or with a second TNFi after initial TNFi failure: results from The British Society for Rheumatology Biologics Register for Rheumatoid Arthritis. Rheumatology. 2017:kex304-kex.

45. Galluccio F, Walker UA, Nihtyanova S, Moinzadeh P, Hunzelmann N, Krieg T, et al. Registries in systemic sclerosis: a worldwide experience. Rheumatology (Oxford). 2011;50(1):60-8.

46. Salmon JH, Cacoub P, Combe B, Sibilia J, Pallot-Prades B, Fain O, et al. Late-onset neutropenia after treatment with rituximab for rheumatoid arthritis and other autoimmune diseases: data from the AutoImmunity and Rituximab registry. RMD Open. 2015;1(1):e000034.

47. Boes M. Role of natural and immune $\operatorname{IgM}$ antibodies in immune responses. Mol Immunol. 2000;37(18):1141-9.

48. Duarte-Rey C, Bogdanos DP, Leung PS, Anaya JM, Gershwin ME. IgM predominance in autoimmune disease: genetics and gender. Autoimmun Rev. 2012;11(6-7):A404-12.

49. Roberts DM, Jones RB, Smith RM, Alberici F, Kumaratne DS, Burns S, et al. Rituximab-associated hypogammaglobulinemia: incidence, predictors and outcomes in patients with multi-system autoimmune disease. J Autoimmun. 2015;57:60-5.

50. Venhoff N, Effelsberg NM, Salzer U, Warnatz K, Peter HH, Lebrecht D, et al. Impact of Rituximab on Immunoglobulin Concentrations and B Cell Numbers after 
Cyclophosphamide Treatment in Patients with ANCA-Associated Vasculitides. PLOS ONE. 2012;7(5):e37626. 


\section{LEGENDS TO FIGURES}

Figure 1: Trends of immunoglobulins following remission induction with cyclophosphamide and RTX in SLE and AAV. Remission induction with cyclophosphamide led to a profound decline in almost all immunoglobulin classes for both diseases at 6 months post-therapy. Following a switch to RTX, using retreatment-on-relapse strategy, IgA and IgG levels remained stable up to 3 cycles in AAV. The bars for all immunoglobulin classes represent mean concentration and the error bars denote standard error of the mean. AAV: antineutrophil cytoplasmic antibody-associated vasculitis; C1-3: cycles 1-3; CyC: cyclophosphamide; LLN: Lower limit of normal, RTX: rituximab; SLE: systemic lupus erythematosus; ULN: Upper limit of normal

Figure 2: Effects of hypogammaglobulinaemia on specific antibody responses, its persistence and response to immunoglobulin replacement therapy. A-B) Specific antibody responses to haemophilus and pneumococcal following a vaccination challenge. C) IgG levels as measured at RTX baseline, 6 months after last RTX cycle and post-switch to bDMARDs. Green-coloured graphs represent patients whom IgG normalised while red-coloured graphs denote low IgG despite a switch in therapy. D) IgG levels as measured pre- and post-therapy with immunoglobulin replacement. The grey-coloured broken-line denote upper limit of normal, blue-coloured broken lines represent lower limit of normal while orange-coloured broken lines denote lower limit of inadequate level to specific antibody test. IGR: immunoglobulin replacement; RTX: rituximab 
Table 1 Baseline characteristics of the 700 RTX-treated RMD patients

\begin{tabular}{|c|c|c|c|}
\hline Characteristic & \multicolumn{3}{|l|}{ Values } \\
\hline \multicolumn{4}{|l|}{ Diagnosis: $\mathrm{n}(\%)$} \\
\hline Rheumatoid arthritis & \multicolumn{3}{|l|}{$507(72.4)$} \\
\hline Systemic lupus erythematosus & \multicolumn{3}{|l|}{$94(13.4)$} \\
\hline ANCA-associated vasculitis & \multicolumn{3}{|l|}{$49(7.0)$} \\
\hline Inflammatory myopathies & \multicolumn{3}{|l|}{$14(2.0)$} \\
\hline Primary Sjogren's syndrome & \multicolumn{3}{|l|}{$9(1.3)$} \\
\hline Systemic sclerosis & \multicolumn{3}{|l|}{$6(0.9)$} \\
\hline Anti-Phospholipid syndrome & \multicolumn{3}{|l|}{$5(0.7)$} \\
\hline Mixed connective tissue disease & \multicolumn{3}{|l|}{$4(0.6)$} \\
\hline Cryoglobulinaemic vasculitis & \multicolumn{3}{|l|}{$2(0.3)$} \\
\hline IgG4-related sclerosing disease & \multicolumn{3}{|l|}{$2(0.3)$} \\
\hline Other CTDs & \multicolumn{3}{|l|}{$8(1.1)$} \\
\hline & $\begin{array}{l}\text { All patients } \\
(n=700)\end{array}$ & $\begin{array}{l}\text { RA } \\
(\mathbf{n}=507)\end{array}$ & $\begin{array}{l}\text { Other RMDs } \\
(n=193)\end{array}$ \\
\hline Age, years: mean (SD) & $55.7(15.9)$ & $60.0(13.2)$ & $44.6(16.8)$ \\
\hline Female: $\mathrm{n}(\%)$ & $550(78.6)$ & $401(79.1)$ & $149(77.2)$ \\
\hline $\begin{array}{l}\text { Disease duration, years: median } \\
\text { (IQR) }\end{array}$ & $7.9(3.4-15.0)$ & $9.6(5.1-17.4)$ & $3.9(1.3-8.6)$ \\
\hline Biologic naïve: n (\%) & $364(52.0)$ & $175(34.5)$ & $189(97.9)$ \\
\hline Prior cyclophosphamide: $\mathrm{n}(\%)$ & $142(20.3)$ & $22(4.4)$ & $120(62.2)$ \\
\hline Concomitant anti-malarials: $\mathrm{n}(\%)$ & $66(9.4)$ & $22(4.3)$ & $42(21.8)$ \\
\hline Concomitant csDMARDs: $\mathrm{n}(\%)$ & $514(73.4)$ & $386(76.1)$ & $128(66.3)$ \\
\hline Methotrexate & $386(55.1)$ & $343(67.7)$ & $43(22.3)$ \\
\hline Mycophenolate mofetil & $55(7.9)$ & $4(0.8)$ & $51(26.4)$ \\
\hline Azathioprine & $36(5.1)$ & $10(2.0)$ & $26(13.5)$ \\
\hline Leflunomide & $26(3.7)$ & $26(5.1)$ & 0 \\
\hline Cyclophosphamide & $8(1.1)$ & 0 & $8(4.1)$ \\
\hline Sulfasalazine & $4(0.6)$ & $3(0.6)$ & $1(0.5)$ \\
\hline Concomitant prednisolone: $\mathrm{n}(\%)$ & $303(43.3)$ & $173(34.1)$ & $130(67.4)$ \\
\hline
\end{tabular}




\begin{tabular}{|c|c|c|c|}
\hline & $\begin{array}{l}\text { All patients } \\
(n=700)\end{array}$ & $\begin{array}{l}\text { RA } \\
(\mathrm{n}=507)\end{array}$ & $\begin{array}{l}\text { Other RMDs } \\
(\mathrm{n}=193)\end{array}$ \\
\hline $\begin{array}{l}\text { Daily prednisolone dose, mg: mean } \\
\text { (SD) }\end{array}$ & $4.8(7.2)$ & $2.8(4.7)$ & $9.9(9.7)$ \\
\hline Ever smoked: n (\%) & $299(42.7)$ & $228(45.0)$ & $71(36.8)$ \\
\hline \multicolumn{4}{|l|}{ Immunoglobulin, g/L: mean (SD) } \\
\hline $\operatorname{IgM}(0.5-2.0)$ & $1.43(1.04)$ & $1.54(1.11)$ & $1.13(0.76)$ \\
\hline $\operatorname{IgA}(0.8-4.0)$ & $3.02(1.44)$ & $3.20(1.37)$ & $2.55(1.50)$ \\
\hline $\operatorname{IgG}(6.0-16.0)$ & $12.36(4.73)$ & $12.13(3.98)$ & $13.0(6.29)$ \\
\hline
\end{tabular}

ANCA: anti-neutrophil cytoplasmic antibody; csDMARDs: conventional synthetic disease modifying anti-rheumatic drugs; CTD: connective tissue disease; RMD: rheumatic and musculoskeletal disease 
Table 2: Baseline predictors of serious infection within 12 months of first cycle RTX

\begin{tabular}{|c|c|c|c|c|}
\hline & $\begin{array}{l}\text { No serious } \\
\text { infection } \\
N=625\end{array}$ & $\begin{array}{c}\text { Serious } \\
\text { infection } \\
N=75\end{array}$ & $\begin{array}{l}\text { Univariable OR } \\
\text { (95\% CI), P-value } \\
\text { (with multiple } \\
\text { imputation) }\end{array}$ & $\begin{array}{l}\text { Multivariable OR } \\
\text { (95\% CI), P-value } \\
\text { (with multiple } \\
\text { imputation) }\end{array}$ \\
\hline $\begin{array}{l}\text { Age, years: median } \\
\text { (IQR) }\end{array}$ & $\begin{array}{ll}57.1 & (45.4- \\
66.4) & \end{array}$ & $\begin{array}{l}64.5 \\
72.8)\end{array}$ & $\begin{array}{l}1.27(1.07-1.50) \\
\text { Per } 10 \text { years of age, } \\
P=0.005\end{array}$ & - \\
\hline Female: n (\%) & $497(79.5)$ & $53(70.6)$ & $\begin{array}{l}0.62(0.36-1.06) \\
P=0.080\end{array}$ & - \\
\hline $\begin{array}{l}\text { Disease duration, } \\
\text { years: median (IQR) }\end{array}$ & $7.9(3.5-14.9)$ & $\begin{array}{ll}8.4 & (2.9- \\
16.4) & \end{array}$ & $\begin{array}{l}1.0(0.98-1.03) \\
\text { Per year, } \\
P=0.517\end{array}$ & $\begin{array}{l}1.03(0.99-1.06) \\
P=0.100\end{array}$ \\
\hline Ever smoked: n (\%) & $259(41.4)$ & $40(53.4)$ & $\begin{array}{l}1.70(1.00-2.61) \\
P=0.051\end{array}$ & - \\
\hline $\begin{array}{l}\text { Previous history of } \\
\text { any cancer: } \mathrm{n}(\%)\end{array}$ & $46(7.4)$ & $11(14.7)$ & $\begin{array}{l}2.16(1.07-4.39) \\
P=0.032\end{array}$ & $\begin{array}{l}3.22(1.32-7.83) \\
P=0.010\end{array}$ \\
\hline $\begin{array}{l}\text { Chronic lung } \\
\text { disease: } \mathrm{n}(\%)\end{array}$ & $129(20.6)$ & $31(41.3)$ & $\begin{array}{l}2.71(1.65-4.46) \\
P<0.001\end{array}$ & $\begin{array}{l}1.79(0.96-3.34) \\
P=0.069\end{array}$ \\
\hline Heart failure: $\mathrm{n}(\%)$ & $11(1.8)$ & $2(2.7)$ & $\begin{array}{l}1.53(0.33-7.03) \\
P=0.585\end{array}$ & - \\
\hline Diabetes: n (\%) & $33(5.3)$ & $9(12.0)$ & $\begin{array}{l}2.45(1.12-5.33) \\
P=0.025\end{array}$ & $\begin{array}{l}1.88(0.71-4.94) \\
P=0.201\end{array}$ \\
\hline $\begin{array}{l}\text { Diagnosis of RA vs } \\
\text { CTDs: } \mathrm{n}(\%)\end{array}$ & $456(73.0)$ & $\begin{array}{l}50(66.7) \\
25(33.3)\end{array}$ & $\begin{array}{l}0.74(0.44-1.24) \\
P=0.249\end{array}$ & $\begin{array}{l}0.49(0.22-1.07) \\
P=0.073\end{array}$ \\
\hline $\begin{array}{l}\text { Previous severe } \\
\text { infection: } \mathrm{n}(\%)\end{array}$ & $58(9.3)$ & $40(53.3)$ & $\begin{array}{l}11.17(6.59-18.94) \\
P<0.001\end{array}$ & $\begin{array}{l}9.29(4.93-17.51) \\
P<0.001\end{array}$ \\
\hline $\begin{array}{l}\text { Previous } \\
\text { cyclophosphamide: } \\
\text { n }(\%)\end{array}$ & $123(19.7)$ & $19(25.3)$ & $\begin{array}{l}1.38(0.79-2.42) \\
P=0.252\end{array}$ & - \\
\hline $\begin{array}{l}\text { Previous biologics: } \\
\text { n }(\%) \\
0 \\
1 \\
2 \\
3 \\
4 \\
\end{array}$ & $\begin{array}{l}316(50.5) \\
137(21.9) \\
105(16.8) \\
52(8.3) \\
15(2.4) \\
\end{array}$ & $\begin{array}{l}48(64.0) \\
11(14.7) \\
10(13.3) \\
4(5.3) \\
2(2.7)\end{array}$ & $\begin{array}{l}0.82(0.64-1.04) \\
\text { Per number of } \\
\text { previous biologics } \\
P=0.102\end{array}$ & $\begin{array}{l}0.84(0.68-1.04) \\
\text { Per number of } \\
\text { previous biologics } \\
P=0.113\end{array}$ \\
\hline $\begin{array}{l}\text { Concomitant } \\
\text { corticosteroid: } \mathrm{n}(\%)\end{array}$ & $256(41.0)$ & $47(62.7)$ & $\begin{array}{l}2.41(1.48-3.97) \\
P<0.001\end{array}$ & - \\
\hline $\begin{array}{l}\text { Corticosteroid dose, } \\
\text { mg: median (IQR) }\end{array}$ & $0(0-7.5)$ & $5(0-10)$ & $\begin{array}{l}1.04(1.01-1.07) \\
P=0.007\end{array}$ & $\begin{array}{l}1.03(0.99-1.07) \\
P=0.151\end{array}$ \\
\hline
\end{tabular}




\begin{tabular}{|c|c|c|c|c|}
\hline & $\begin{array}{c}\text { No serious } \\
\text { infection } \\
N=625\end{array}$ & $\begin{array}{c}\text { Serious } \\
\text { infection } \\
N=75\end{array}$ & $\begin{array}{c}\text { Univariable OR } \\
\text { (95\% CI), P-value } \\
\text { (with multiple } \\
\text { imputation) }\end{array}$ & $\begin{array}{l}\text { Multivariable OR } \\
\text { (95\% CI), P-value } \\
\text { (with multiple } \\
\text { imputation) }\end{array}$ \\
\hline $\begin{array}{l}\text { Concomitant } \\
\text { csDMARDs: } \mathrm{n}(\%)\end{array}$ & $470(75.2)$ & $44(58.7)$ & $\begin{array}{l}0.47(0.29-0.77) \\
P=0.003\end{array}$ & $\begin{array}{l}0.63(0.35-1.14) \\
P=0.128\end{array}$ \\
\hline $\begin{array}{l}\text { RTX-associated } \\
\text { neutropaenia: } \mathrm{n}(\%)\end{array}$ & $6(0.96)$ & $5(6.67)$ & $\begin{array}{l}7.37(2.19-24.77) \\
P=0.001\end{array}$ & $\begin{array}{l}13.26(3.12-56.44) \\
P<0.001\end{array}$ \\
\hline $\begin{array}{l}\text { Low } \operatorname{IgM}(<0.5 \mathrm{~g} / \mathrm{L}) \text { : } \\
\mathrm{n}(\%)\end{array}$ & $42(6.7)$ & $15(20.0)$ & $\begin{array}{l}3.47(1.82-6.63) \\
P<0.001\end{array}$ & $\begin{array}{l}2.07(0.86-4.99) \\
P=0.103\end{array}$ \\
\hline $\begin{array}{l}\text { Low IgA }(<0.8 \mathrm{~g} / \mathrm{L}) \text { : } \\
\text { n }(\%)\end{array}$ & $11(1.8)$ & $4(5.3)$ & $\begin{array}{l}3.14(0.98-10.14) \\
P=0.055\end{array}$ & - \\
\hline $\begin{array}{l}\text { Low IgG }(<6.0 \mathrm{~g} / \mathrm{L}) \text { : } \\
\mathrm{n}(\%)\end{array}$ & $20(3.2)$ & $14(18.7)$ & $\begin{array}{l}7.28(3.48-15.25) \\
P<0.001\end{array}$ & $\begin{array}{l}2.80(1.02-7.67) \\
P=0.045\end{array}$ \\
\hline $\begin{array}{l}\text { Naïve B-cell:* } \\
\text { median (IQR) }\end{array}$ & $\begin{array}{l}72.2 \\
122.0)\end{array}$ & $\begin{array}{l}43.3 \\
102.0)\end{array}$ & $\begin{array}{l}1.000 \quad(0.997- \\
1.002), P=0.728\end{array}$ & - \\
\hline $\begin{array}{l}\text { Memory B-cell:* } \\
\text { median (IQR) }\end{array}$ & $18.5(8.3-35.5)$ & $\begin{array}{l}10.7 \quad(5.0- \\
39.1)\end{array}$ & $\begin{array}{l}0.999 \\
1.006), P=0.743\end{array}$ & - \\
\hline $\begin{array}{l}\text { Plasmablasts:* } \\
\text { median (IQR) }\end{array}$ & $1.9(0.8-3.8)$ & $1.9(0.9-)$ & $\begin{array}{l}1.016)(0.991- \\
1.043), P=0.215\end{array}$ & $\begin{array}{l}1.02(0.991-1.051) \\
P=0.173\end{array}$ \\
\hline
\end{tabular}

*(count $\mathrm{x} 10^{9}$ cells/L) for each subset multiply by 1000 prior to analysis

CTD: connective tissue disease; csDMARDs: conventional synthetic disease modifying antirheumatic drugs; IQR: interquartile range; RA: rheumatoid arthritis; RTX: rituximab 
Table 3: Predictors of serious infection during cycles 2-4 of RTX

\begin{tabular}{|c|c|c|c|c|}
\hline & $\begin{array}{l}\text { No serious } \\
\text { infection } \\
\mathbf{N}=\mathbf{1 2 0 8}\end{array}$ & $\begin{array}{c}\text { Serious } \\
\text { infection } \\
N=111\end{array}$ & $\begin{array}{c}\text { Univariable OR } \\
\text { (95\% CI), P-value } \\
\text { (with multiple } \\
\text { imputation) }\end{array}$ & $\begin{array}{l}\text { Multivariable OR } \\
\text { (95\% CI), P-value } \\
\text { (with multiple } \\
\text { imputation) }\end{array}$ \\
\hline $\begin{array}{l}\text { Age, years: mean } \\
\text { (SD) }\end{array}$ & $55.5(14.8)$ & $59.8(15.7)$ & $\begin{array}{l}1.03(1.00-1.05) \\
\text { Per } 10 \text { years of age, } \\
P=0.007\end{array}$ & - \\
\hline Female: (\%) & 80.1 & 73.0 & $\begin{array}{l}0.64(0.35-1.17) \\
P=0.149\end{array}$ & $\begin{array}{l}0.70(0.39-1.24) \\
P=0.219\end{array}$ \\
\hline $\begin{array}{l}\text { Previous history of } \\
\text { any cancer: }(\%)\end{array}$ & 9.0 & 14.4 & $\begin{array}{l}1.93(0.86-4.35), \\
P=0.112\end{array}$ & $\begin{array}{l}3.24(1.50-7.01) \\
P=0.003\end{array}$ \\
\hline $\begin{array}{l}\text { Chronic lung disease: } \\
(\%)\end{array}$ & 19.6 & 39.6 & $\begin{array}{l}3.51(1.94-6.35) \\
P<0.001\end{array}$ & $\begin{array}{l}2.24(1.25-4.02) \\
P=0.007\end{array}$ \\
\hline Heart failure: (\%) & 1.2 & 5.4 & $\begin{array}{l}2.60(0.87-7.80) \\
P=0.087\end{array}$ & $\begin{array}{l}5.75(1.45-22.80) \\
P=0.013\end{array}$ \\
\hline Diabetes: (\%) & 5.9 & 13.5 & $\begin{array}{l}9.42(1.87-47.53) \\
P=0.007\end{array}$ & $\begin{array}{l}2.61(1.14-5.97) \\
P=0.023\end{array}$ \\
\hline $\begin{array}{l}\text { Previous severe } \\
\text { infection: }(\%)\end{array}$ & 8.9 & 37.8 & $\begin{array}{l}10.10 \quad(4.94-20.65), \\
P<0.001\end{array}$ & $\begin{array}{l}\text { 6.32 (3.11-12.82), } \\
P<0.001\end{array}$ \\
\hline $\begin{array}{l}\text { Corticosteroid dose, } \\
\text { mg: median (IQR) }\end{array}$ & $0(0-5)$ & $3.75(0-7.50)$ & $\begin{array}{l}1.11(1.05-1.16), \\
P<0.001\end{array}$ & $\begin{array}{l}1.08(1.02-1.13), \\
P=0.005\end{array}$ \\
\hline $\begin{array}{l}\text { Concomitant } \\
\text { csDMARDs: }(\%)\end{array}$ & 64.0 & 59.5 & $\begin{array}{l}0.80(0.47-1.35) \\
P=0.395\end{array}$ & - \\
\hline Full dose RTX: (\%) & 93.3 & 91.9 & $\begin{array}{l}0.65(0.26-1.62) \\
P=0.351\end{array}$ & - \\
\hline $\begin{array}{l}\text { Time-to-RTX, } \\
\text { retreatment, weeks: } \\
\text { median (IQR) }\end{array}$ & $\begin{array}{ll}49.3 \quad(36.4- \\
64.7)\end{array}$ & $\begin{array}{ll}53.0 & (38.4- \\
86.7) & \end{array}$ & $\begin{array}{l}1.01(1.00-1.01), \\
P=0.003\end{array}$ & $\begin{array}{l}1.01(1.00-1.02), \\
P=0.003\end{array}$ \\
\hline $\begin{array}{l}\text { RTX-associated } \\
\text { neutropaenia: }(\%)\end{array}$ & 0.58 & 3.60 & $\begin{array}{l}8.07(1.53-42.72), \\
P=0.014\end{array}$ & $\begin{array}{l}16.56(3.82-71.72), \\
P<0.001\end{array}$ \\
\hline $\begin{array}{l}\text { IgM level, g/L: } \\
\text { mean(SD) }\end{array}$ & $0.95(0.78)$ & $0.97(1.57)$ & $\begin{array}{l}1.05(0.82-1.33), \\
P=0.719\end{array}$ & $\begin{array}{l}1.24(0.96-1.60), \\
P=0.094\end{array}$ \\
\hline $\begin{array}{l}\text { IgA level, g/L: mean } \\
\text { (SD) }\end{array}$ & $2.84(1.44)$ & $2.74(1.61)$ & $\begin{array}{l}0.93(0.77-1.11) \\
P=0.399\end{array}$ & - \\
\hline $\begin{array}{l}\text { IgG level, g/L: mean } \\
\text { (SD) }\end{array}$ & $11.06(3.79)$ & $9.81(4.30)$ & $\begin{array}{l}0.89(0.83-0.96), \\
P=0.002\end{array}$ & $\begin{array}{l}0.88(0.81-0.96), \\
P=0.005\end{array}$ \\
\hline
\end{tabular}




\begin{tabular}{|c|c|c|c|c|}
\hline & $\begin{array}{c}\text { No serious } \\
\text { infection } \\
N=1208\end{array}$ & $\begin{array}{c}\text { Serious } \\
\text { infection } \\
N=111\end{array}$ & $\begin{array}{l}\text { Univariable OR } \\
\text { (95\% CI), P-value } \\
\text { (with multiple } \\
\text { imputation) }\end{array}$ & $\begin{array}{l}\text { Multivariable OR } \\
\text { (95\% CI), P-value } \\
\text { (with multiple } \\
\text { imputation) }\end{array}$ \\
\hline $\begin{array}{l}\text { Percentage change in } \\
\text { IgM level, \%: median } \\
\text { (IQR) }\end{array}$ & $\begin{array}{l}36.2 \quad(22.5- \\
50.0)\end{array}$ & $\begin{array}{l}36.3 \\
58.2)\end{array}$ & $\begin{array}{l}1.00(0.99-1.01) \\
P=0.800\end{array}$ & - \\
\hline $\begin{array}{l}\text { Percentage change in } \\
\text { IgA level, \%: } \\
\text { median(IQR) }\end{array}$ & $\begin{array}{l}8.7 \quad(-3.3- \\
20.4)\end{array}$ & $\begin{array}{l}9.0 \quad(-5.9 \quad- \\
28.4)\end{array}$ & $\begin{array}{l}1.01(1.00-1.02), \\
P=0.190\end{array}$ & - \\
\hline $\begin{array}{l}\text { Percentage in IgG } \\
\text { level, \%: median } \\
\text { (IQR) }\end{array}$ & $\begin{array}{l}10.2(-0.80- \\
20.6)\end{array}$ & $\begin{array}{lll}13.8 \quad(0.0 \quad- \\
28.1)\end{array}$ & $\begin{array}{l}1.01(0.99-1.02), \\
P=0.381\end{array}$ & - \\
\hline $\begin{array}{l}\text { Pre-RTX naïve B- } \\
\text { cell:* median (IQR) }\end{array}$ & $\begin{array}{l}16.2 \\
51.5)\end{array}$ & $5.8(0.2-35.2)$ & $\begin{array}{l}1.001(0.998-1.003) \\
P=0.565\end{array}$ & $\begin{array}{l}1.002(0.993-1.005) \\
P=0.139\end{array}$ \\
\hline $\begin{array}{l}\text { Pre-RTX memory B- } \\
\text { cell:* median (IQR) }\end{array}$ & $1.4(0.6-3.3)$ & $1.3(0.4-4.0)$ & $\begin{array}{l}0.993(0.958-1.030) \\
P=0.719\end{array}$ & $\begin{array}{l}0.970(0.928-1.014) \\
P=0.176\end{array}$ \\
\hline $\begin{array}{l}\text { Pre-RTX } \\
\text { plasmablasts:* } \\
\text { median (IQR) }\end{array}$ & $1.0(0.3-2.1)$ & $0.8(0.0-2.7)$ & $\begin{array}{l}1.005(0.950-1.062) \\
P=0.867\end{array}$ & - \\
\hline $\begin{array}{l}\text { Complete B-cell } \\
\text { depletion: }(\%)\end{array}$ & 73.4 & 72.1 & $\begin{array}{l}0.80(0.46-1.40), \\
P=0.435\end{array}$ & $\begin{array}{l}0.65(0.39-1.24), \\
P=0.191\end{array}$ \\
\hline
\end{tabular}

*(count x $10^{9}$ cells/L) for each subset multiply by 1000 prior to analysis

CTD: connective tissue disease; csDMARDs: conventional synthetic disease modifying antirheumatic drugs; IQR: interquartile range; RA: rheumatoid arthritis; RTX: rituximab 
Table 4: Serious infection rates in patients with IgM and IgG levels <LLN for at least 4 months during RTX therapy

\begin{tabular}{|c|c|c|c|c|}
\hline & \multirow[t]{2}{*}{$\begin{array}{l}\text { Group 1: Ig }<\mathrm{LLN} \text { at } \\
\text { RTX initiation }(\mathrm{n}=57)\end{array}$} & \multicolumn{2}{|c|}{$\begin{array}{l}\text { Group 2: Patients who developed Ig<LLN during } \\
\text { RTX (n=196) }\end{array}$} & \multirow{2}{*}{$\begin{array}{l}\text { Group 3: Those who never } \\
\text { developed Ig<LLN during } \\
\text { RTX (n=482) }\end{array}$} \\
\hline & & Before Ig $<\mathrm{LLN}$ & During/After Ig $<$ LLN & \\
\hline \multicolumn{5}{|c|}{ IgM } \\
\hline Total Exposure (PY) & 235.5 & 538.1 & 528.2 & 1700.9 \\
\hline No of SIE & 25 & 53 & 74 & 156 \\
\hline Rate of SIE/100 PY (95\% CI) & $10.6(6.9$ to 15.7$)$ & $9.8(7.4$ to 12.9$)$ & $14.0(11.0$ to 16.6$)$ & $9.2(7.8$ to 10.7$)$ \\
\hline \multicolumn{5}{|c|}{ IgG } \\
\hline Total Exposure (PY) & 122.1 & 123.5 & 136.0 & 2457.1 \\
\hline No of SIE & 20 & 15 & 29 & 238 \\
\hline Rate of SIE/100 PY (95\% CI) & $16.4(10.0$ to 25.3$)$ & $12.1(6.8$ to 20.0$)$ & $21.3(14.3$ to 30.6$)$ & $9.7(8.5$ to 11.0$)$ \\
\hline
\end{tabular}

LLN: lower limit of normal; PY: patient-year; SIE: serious infection event; RTX: rituximab 


\section{Acknowledgements}

The authors would like to thank the clinicians, nurses, pharmacists, study coordinators and lab technicians at the Leeds Biologics, Connective Tissue Disease and Vasculitis Clinic particularly Sarah Bingham, Benazir Saleem, Jacqueline Nam, Aamir Aslam, Andrew Barr, Jacqueline Andrews, Colin Pease, Mike Martin, Francesco Del Galdo, Dominic Bryer, Lynda Bailey, Tina Hawkins, Joanne Sanderson, Claire Sanderson, James Goulding, Huma Cassamoali and Sabina Khan for their substantial contribution in the acquisition of the data. 